IP Periodica Polytechnica

Social and Management

Sciences

26(1), pp. 30-37, 2018

https://doi.org/10.3311/PPso.10206

Creative Commons Attribution (i)

RESEARCH ARTICLE

\section{Assessing the Relationship Between Entrepreneurial Orientation, Reputational Resources and Absorptive Capability: A Resource-Based Approach}

\author{
Orlando Lima Rua ${ }^{1 *}$, Alexandra França ${ }^{2}$
}

Received 24 October 2016; accepted after revision 17 November 2016

\begin{abstract}
Building on well established theories, our research explores the influence of entrepreneurial orientation on reputational resources and absorptive capacity of knowledge exploitation of Portuguese small and medium enterprises (SMEs) of footwear associated to the Portuguese Footwear, Components and Leather Goods Association (APICCAPS).

Therefore, a quantitative methodological approach was used, conducting a descriptive, exploratory and transversal empirical study, having applied a questionnaire to a sample of Portuguese SMEs.

Based on survey data from 42 firms, our empirical results indicate that globally entrepreneurial orientation have a positive and significant influence on knowledge exploitation and that the entrepreneurial orientation's dimensions that most contribute to this end are innovation and risk-taking.

Moreover, the processes for exploitation of reputational resources and knowledge became an essential element for firms to adapt to changes in the competitive environment. The exploitation of this resources and capacities should be undertaken with innovation, proactivity and risk-taking.
\end{abstract}

\section{Keywords}

entrepreneurial orientation, reputational resources, absorptive capabilities, SMEs, Portuguese footwear industry

${ }^{1}$ Polytechnic of Porto/ISCAP/CEOS.PP,

APNOR/UNIAG,

School of Accounting and Administration

Rua Jaime Amorim Lopes, s/n, 4465-004 S. M. Infesta, Portugal

${ }^{2}$ University of Minho,

School of Economics and Management,

Campus de Gualtar 4710-057 Braga, Portugal

"Corresponding author, e-mail: orua@iscap.ipp.pt

\section{Introduction}

Entrepreneurial orientation is a strategic orientation of a company that encompasses specific entrepreneurs aspects such as style, methods and decision-making practices (Frank et al., 2010), constituting a capacity that can attract resources to exploit opportunities (Alvarez and Busenitz, 2001).

In the field of strategic management has focused on the intangible resources of firms have attracted considerable interest in organizational and strategy research (Barney, 1991). In particular, scholars have focused a great deal of attention on a subclass of intangible assets that is called "social approval assets" because they develop their value from favorable collective perceptions (Pfarrer et al., 2010). The important intangible resources studied in this research are the reputational resources, since it helps distinguish firms from competitors (Peteraf, 1993), reduces information asymmetry, consumer uncertainty and substitutes expensive governance mechanisms. Moreover, reputation has been linked to organizational performance. Therefore, it appears to be a key variable to understand why some organizations outperform others (Boyd et al., 2010).

On the other hand, strategic management's literature also has focused on dynamic capabilities (for a review see Barreto, 2010). The firms' success depends not only on its' resources and capabilities, but also the ability to adapt itself to the industry contingencies and the markets in which operates. Firms may possess resources but must display dynamic capabilities otherwise shareholder value will be destroyed (Bowman and Ambrosini, 2003). It is in this context that emerges the Dynamic Capabilities View (DCV) (Amit and Schoemaker, 1993; Teece et al., 1997) to support the adjustment to environmental change.

In a dynamic and turbulent environment, knowledge represents a critical resource to create value and to develop and sustain competitive advantages (Teece et al., 1997). However, fast changing environments, technologies and competitiveness intensify the challenges firms face in attaining self-sufficiency in knowledge creation (Camisón and Forés, 2010).

$\mathrm{DCV}$ is not divergent but rather an important stream of Resource-Based View (RBV) to gain competitive advantage in increasingly demanding environments (Ambrosini and 
Bowman, 2009; Barreto, 2010; Eisenhardt and Martin, 2000; Wang and Ahmed, 2007). Monteiro, Soares and Rua (in press) defend that in versatile markets the firms' capabilities should be dynamic and managers must display the ability to ensure consistency between the business environment and strategy in order to continuously renew skills.

Dynamic capabilities as a mind-set constantly integrate, reconfigure, renew and recreate its core capabilities in response to the ever changing environment in order to achieve and sustain competitive advantage (Wang and Ahmed, 2007). Moreover, these capabilities sense and shape opportunities and threats, seize opportunities, and maintain competitiveness by enhancing, combining, protecting, and reconfiguring the businesses' intangible and tangible resources (Teece, 2007).

Absorptive capacity (ACAP) has become one of the most significant constructs in the last twenty years. Absorptive capacity is the dynamic capability that allows firms to gain and sustain a competitive advantage through the management of the external knowledge (Camisón and Forés, 2010).

Building on well established theories, our research aims at analyzing the influence of entrepreneurial orientation in reputational resources and exploitation of knowledge of Portuguese SMEs exporting footwear, by studying the contributions of this capability in such construct.

\section{Theoretical framework}

\subsection{Entrepreneurial orientation}

Entrepreneurial orientation emerged from entrepreneurship definition which suggests that a company's entrepreneurial degree can be measured by how it take risks, innovate and act proactively (Miller, 1983). Entrepreneurship is connected to new business and entrepreneurial orientation relates to the process of undertaking, namely, methods, practices and decision-making styles used to act entrepreneurially. Thus, the focus is not on the person but in the process of undertake (Wiklund, 2006).

Companies can be regarded as entrepreneurial entities and entrepreneurial behaviour can be part of its activities (Covin and Slevin, 1991). Entrepreneurial orientation emerges from a deliberate strategic choice, where new business opportunities can be successfully undertaken (Lumpkin and Dess, 1996). Thus, there is an entrepreneurial attitude mediating the vision and operations of an organization (Covin and Miles, 1999).

Several empirical studies indicate a positive correlation between entrepreneurial orientation and organizational growth (e.g. Miller, 1983; Covin and Slevin, 1991; Lumpkin and Dess, 1996; Wiklund, 2006; Davis et al., 2010; Frank et al., 2010). Similarly, other studies also confirm that entrepreneurial orientation has a positive correlation with export's performance, enhancing business growth (e.g. Zahra and Garvis, 2000; Okpara, 2009).

The underlying theory of entrepreneurial orientation scale is based on the assumption that the entrepreneurial companies are different from the remaining (Kreiser et al., 2002), since such are likely to take more risks, act more proactive in seeking new businesses and opportunities (Khandwalla, 1977; Mintzberg, 1973).

Entrepreneurial orientation has been characterized by certain constructs that represent organization's behaviour. Starting from the Miller (1983) definition, three dimensions were identified: innovativeness, proactiveness and risk-taking, which collectively increase companies' capacity to recognize and exploit market opportunities well ahead of competitors (Zahra and Garvis, 2000). However, Lumpkin and Dess (1996) propose two more dimensions to characterize and distinguish entrepreneurial process: competitive aggressiveness and autonomy. In this study only innovation, proactiveness and risk-taking will be considered, as they are the most consensual and used dimensions to measure entrepreneurial orientation (e.g. Covin and Miller, 2014; Covin and Slevin, 1989, 1991; Davis et al, 2010; Frank et al., 2010; Kreiser et al, 2002; Lisboa, Skarmeas and Lages, 2011; Miller, 1983; Okpara, 2009; Wiklund and Shepherd, 2005; Zahra and Covin, 1995; Zahra and Garvis, 2000).

\subsection{Reputational resources}

The new paradigm of today's world economy is characterized by the mobility of production resources and the ability to combine them in an efficient way. The strategic management research has recognized the importance of studying the companies' resources and capabilities and its usefulness to achieve competitive advantage. This perspective is consistent with the Resource-Based View (RBV).

Scholars argue that resources form the basis of firm strategies (Barney, 1991). Therefore, firm resources and strategy cooperate to create positive returns. Firms employ both tangible resources (such as physical infrastructures and financial resources) and intangible resources (like knowledge and brand equity) in the development and implementation of strategies. However, intangible resources are more likely than tangible resources to produce a competitive advantage, since they are often rare and socially complex, thereby making them difficult to imitate (Hitt et al., 2001). Thus, intangible resources are considered strategic resources (Amit and Schoemaker, 1993).

Intangibles resources have three intrinsic characteristics that distinguish them from tangible resources (Molloy et al., 2011). First, intangibles do not deteriorate with use, since these resources are expected to confer benefits for an indeterminate period of time (Cohen, 2005). Secondly, multiple managers can use the intangibles resources simultaneously, for example, the use of a brand is available for all managers. Finally, the intangibles resources are immaterial, making them difficult to exchange, as they often cannot be separated from its' owner (Marr and Roos, 2005).

The existing literature suggests six types of resources that are particularly important sources of export venture competitive advantage: reputational resources; access to financial resources; human resources; cultural resources; relational resources; and, informational resources (Morgan et al., 2006). 
The RBV describes reputation as an intangible resource that is consequent from combinations of internal investments and external evaluations (Shamsie, 2003). This "social approval assets" can positively impact customer behavior, loyalty and consumption experience (Cretu and Brodie, 2007; Pfarrer et al., 2010).

Reputational resources concern intangible image-based assets available to the firm and can be a differentiation factor in the target market (Hall, 1992). These resources must be understood as a source of competitive advantage, since they are rare, difficult to imitate and transfer and permeate the company's activity (Barney, 1991).

The most important reputational asset relevant to export performance identified in the literature is brand equity. This concept is associated to a set of assets linked to the name and symbol of the brand that adds value to the initial value of the product or service, such brand name awareness, distinctiveness of brand image, appeal of brand 'personality' and strength of brand image (Morgan et al., 2006). This valuable intangible resource allows the company to build and protect its market share, enhance marketing investments and introduce new products in the export target market more easily (Aaker, 2010).

Aaker (1991) identifies brand awareness as the potential customer ability to recognize that a brand has certain category. This recognition helps a brand to distinguish from others. Brand associations consist of brand-related thoughts, feelings, perceptions, smells, colors, music, images, experiences, beliefs and attitudes (Kotler and Keller, 2011). Brand loyalty is defined as the attachment that a customer has to a brand. Perceived quality can be defined as customers' judgment about a product's overall excellence or superiority. Consequently, perceived quality is a overall feeling about a brand and does not imply the actual quality of a product (Aaker, 1991).

Resources that are valuable, unique, and difficult to imitate can provide competitive advantages (Amit and Schoemaker 1993; Barney 1991). In turn, these advantages provide positive returns (Peteraf 1993). Thus, firms need to continually analyse and interpret changing market trends and quickly recognize new opportunities in order to create competitive products (Tzokas et al., 2015), since it increases the engagement with innovation, which contributes, for example, to creating new products and services, seeking new opportunities and new markets (Miller 1983; Lumpkin and Dess, 1996). Ultimately, the following research hypothesis is tested:

H1: Entrepreneurial orientation influences positively reputational resources.

\subsection{Absorptive capacity of exploitation of knowledge}

In order to survive certain pressures, companies need to recognize, assimilate and apply new external knowledge for commercial purposes (Jansen et al., 2005). This ability, known as absorptive capacity (Cohen and Levinthal, 1990), emerges as an underlying theme in the organizational strategy research
(Jansen et al., 2005). Cohen and Levinthal (1990) conceptualize ACAP as the firms' ability to identify, assimilate, and exploit knowledge acquired from external sources. As such, ACAP facilitates knowledge accumulation and its subsequent use. Thus, this ability access and use new external knowledge, regarded as an intangible asset, is critical to success and depends mainly on prior knowledge level, since it is this knowledge that will facilitate the identification and processing of new one. This prior knowledge not only includes the basic capabilities, such as shared language, but also recent technological and scientific data or learning skills. By analysing this definition is found that absorptive capacity of knowledge only three dimensions: the ability to acquire external knowledge; the ability to assimilate it inside; and the ability to apply it (Cohen and Levinthal, 1990). Zahra and George (2002) broaden the concept of ACAP from the original three dimensions (identify, assimilate, and exploit) to four dimensions (acquire, assimilate, transform, and exploit).

ACAP is a good example of a dynamic capability since it is embedded in a firm's routines. It combines the firm's resources and capabilities in such a way that together they influence "the firm's ability to create and deploy the knowledge necessary to build other organizational capabilities" (Zahra and George, 2002, p. 188).

According to Zahra and George (2002) ACAP is divided in Potential Absorptive Capacity (PACAP), including knowledge acquisition and assimilation, and Realized Absorptive Capacity (RACAP) that focuses on transformation and exploitation of that knowledge. PACAP reflects the companies' ability to acquire and assimilate knowledge that is vital for their activities. Knowledge acquisition the identification and acquisition and assimilation is related to routines and processes that permit to analyse, process, interpret and understand the external information. RACAP includes knowledge transformation and exploitation, where transformation is the ability to develop and perfect routines that facilitate the integration of newly acquired knowledge in existing one, exploitation are routines which enhance existing skills or create new ones by incorporating acquired and transformed knowledge internally.

Jansen et al. (2005) defend that, although company's exposure to new knowledge, is not sufficient condition to successfully incorporate it, as it needs to develop organizational mechanisms which enable to synthesize and apply newly acquired knowledge in order to cope and enhance each ACAP dimension. Thus, there are coordination mechanisms that increase the exchange of knowledge between sectors and hierarchies, like multitasking teams, participation in decision-making and job rotation. These mechanisms bring together different sources of expertise and increase lateral interaction between functional areas. The system mechanisms are behaviour programs that reduce established deviations, such as routines and formalization. Socialization mechanisms create a broad and tacit 
understanding of appropriate rules of action, contributing to a common code of communication.

Studying absorptive capacity offers fascinating insights for the strategic management literature and provide new information regarding how firms may develop important sources of sustainable competitive advantages (Jansen et al., 2005). In this paper the focus is on the exploitation of knowledge.

Dynamic capabilities refer to "the firm's ability to integrate, build, and reconfigure internal and external competences to address rapidly changing environments" (Teece et al., 1997, p. 516).

Barreto (2010, p. 271) argued that a "dynamic capability is the firm's potential to systematically solve problems, formed by its propensity to sense opportunities and threats, to make timely and market-oriented decisions, and to change its resource base". On the other hand, dynamic capabilities enable companies to create, develop and protect resources allowing them to attain superior performance in the long run, are constructed (not acquired in the market), dependent on experience and are embedded in the company's organizational processes (Ambrosini and Bowman, 2009), not directly affecting the outputs, but contributing through the impact they have on operational capabilities (Teece et al., 1997). These capabilities refer to a firm's capacity to deploy resources, usually in combination, using both explicit and tacit elements (such as know-how and leadership). For this reason, capabilities are often firm-specific and are developed over time through complex interactions between the firm's resources (Amit and Schoemaker, 1993). Maintaining these capabilities requires a management that is able to recognize adversity and trends configure and reconfigure resources, adapt processes and organizational structures in order to create and seize opportunities, while remaining aligned with customer preferences. Indeed, dynamic capabilities allow businesses to achieve superior long-term performance (Teece, 2007).

Firms, therefore, need to continually analyse and interpret changing market trends and quickly recognize new opportunities in order to create competitive products (Tzokas, Kim, Akbar and Al-Dajani, 2015). The ACAP construct encompasses an outward-looking perspective that deals with the identification and generation of useful external knowledge and information and an inward-looking component that is related with how this knowledge is analysed, combined with existing knowledge, and implemented in new products, new technological approaches, or new organizational capabilities (Cohen and Levinthal, 1990).

Ultimately, the following research hypothesis is tested:

$\mathrm{H} 2$ : Entrepreneurial orientation influences positively exploitation of knowledge.
We present in Fig. 1 the theoretical model that will be explored in this research, which represents the explanatory variables (entrepreneurial orientation) and explained variables (reputational resources and absorptive capacity of knowledge exploitation).

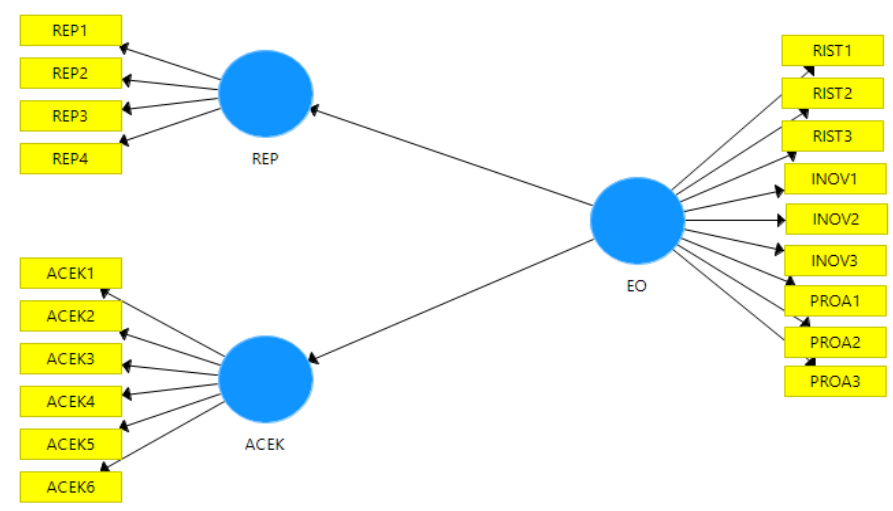

Key:

EO - Entrepreneurial orientation (INOV - Innovativeness, PROA -

Proactiveness, RIST - Risk-taking).

REP - Reputational resources.

ACEK - Absorptive capacity of exploitation of knowledge.

Fig. 1 Research conceptual model

\section{Methodology}

\subsection{Setting and data collection}

To test the hypothesis a sample of Portuguese footwear companies was used, that meet the following criteria: companies in which at least $50 \%$ of income comes from exports of goods, or companies in which at least $10 \%$ of income comes from exports of goods and the export value is higher than 150.000 Euros (INE, 2011).

Data collection was implemented through electronic questionnaire, associating a link to the survey that was online. To reduce misunderstandings, the questionnaire was validated by the research department of Portuguese Footwear, Components and Leather Goods Association (APICCAPS).

We were provided with a database of 231 companies. Only 167 companies fulfilled the parameters, and were contacted by email by APICCAPS to respond to the questionnaire. Subsequently, all companies were contacted by the authors via e-mail and telephone, to ensure a higher rate of valid responses. The questionnaires began on April 22 and ended on July 22, 2014. After finishing the data collection period, 42 valid questionnaires were received, representing a $25 \%$ response rate. This response rate is considered quite satisfactory, given that the average of top management survey response rates are in the range of $15 \%-20 \%$ (Menon et al., 1999).

In this investigation we chose a non-probabilistic and convenient sample since it respondent were chosen for being members of APICCAPS. 


\subsection{Measures}

For assessment of entrepreneurial orientation was used Covin and Slevin's scale (1989), that consists in nine items: three for innovativeness, three for proactiveness and three for risk-taking, having been used a five point Likert scale, where 1 means "strongly disagree" and 5 "strongly agree".

To measure the reputational resources this study used the four items scale proposed by Morgan, Vorhies and Schlegelmilch (2006). A five point Likert scale was used to measure each item, where 1 means "strongly disagree" and 5 "strongly agree".

For assessment of exploitation of knowledge, and based in Jansen et al. (2005), it was operationalized the company's ability to explore new external knowledge into their current operations, through six questions (e.g. Jansen et al., 2005; Zahra and George, 2002). A five point Likert scale was used to measure each item, where 1 means "strongly disagree" and 5 "strongly agree".

\section{Results}

The structural equation model is a multiple regression analysis, with reflective indicators that are presented as an image of the unobserved theoretical construct, representing observed variables or measures, with the objective of strengthening the relationship of influence between the constructs (Maroco, 2010). The simple correlation between these indicators with their construct must have a value equal to or higher than 0.707 so that the shared variance between the construct and their indicators is higher than the error variance (Carmines and Zeller, 1979).

Partial Least Squares (PLS) is a technique that best fits predictive applications (exploratory analysis) and theory development when it is not soundly established (Roldán and Cepeda, 2014). This technique, on one hand, maximize the explained variance of the dependent variables (latent or observed, or both) and estimate structural models with small samples (Chin and Newsted, 1999; Reinartz, Haenlein and Henseler, 2009). On the other hand, it estimates reflective and formative measurement models without identification problems (Chin, 2010). PLS appear to be a preferable option for researchers with samples below 250 observations (42 in this study) (Reinartz et al., 2009).

In order to verify the reliability of overall variables we estimated the stability and internal consistency through Cronbach's alpha $(\alpha)$. Generally, an instrument or test is classified with appropriate reliability when $\alpha$ is higher or equal to 0.70 (Nunally, 1978; Chin, 2010). The result of 0.939 achieved for all variables is considered excellent, confirming the sample's internal consistency (Pestana and Gageiro, 2000). Table 1 show all constructs largely achieved the required level.

Table 1 Cronbach's Alpha of multidimensional variables

\begin{tabular}{lll}
\hline Construct & Cronbach Alpha & p values \\
\hline EO & .757 & .000 \\
REP & .905 & .000 \\
ACEK & .898 & .000 \\
\hline
\end{tabular}

We also use the composite reliability coefficient to assess construct validity (Chin, 1998). This coefficient reflects construct adequacy for a level higher than 0.6 using confirmatory factor analysis (Gefen and Straub, 2005), as in our case. Table 2 illustrates that the studied constructs (all multidimensional) highly exceeded the minimum required for a good fit.

Table 2 Composite reliability coefficient of multidimensional variables

\begin{tabular}{lll}
\hline Construct & Composite reliability & p values \\
\hline EO & .791 & .000 \\
REP & .933 & .000 \\
ACEK & .922 & .000 \\
\hline
\end{tabular}

For validity assessment, two subtypes are usually examined: convergent and discriminant validity. Convergent validity implies that a set of indicators represents one and the same underlying construct (Henseler et al., 2009). Fornell and Larcker (1981) suggest using the Average Variance Extracted (AVE) criterion and that an AVE value of at least 0.5 indicates sufficient convergent validity. Next table demonstrates that only entrepreneurial orientation is below the minimum required.

Table 3 Convergent validity

\begin{tabular}{lll}
\hline Construct & AVE & $\boldsymbol{p}$ values \\
\hline EO & .322 & .000 \\
REP & .777 & .000 \\
ACEK & .665 & .000 \\
\hline
\end{tabular}

Discriminant validity is the degree to which any single construct is different from the other constructs in the model. To have discriminant validity a construct must exhibit weak correlations with other latent variables that measure different phenomena. There are two measures of discriminant validity in PLS. The Fornell-Larcker criterion (1981) recommends that the AVE should be greater than the variance between a given construct and the other with which it shares the model. The second criterion suggests that the loading of each indicator is expected to be greater than all of its cross-loadings (Henseler et al., 2009).

We can observe the explanatory power of each variable in the model. Entrepreneurial orientation is the only purely explanatory variable and reputational resources and absorptive capacity of knowledge exploitation the explained variables. Chin (1998) distinguishes the explanatory power from moderate to substantial. Table 4 expresses the good results in terms of discriminant validity of the research model, confirming that constructs do differ significantly. 
Table 4 Discriminant validity

\begin{tabular}{lccc}
\hline Fornell-Larcker Criterion & EO & ACEK & REP \\
\hline EO & .568 & & \\
ACEK & .557 & .815 & \\
REP & .488 & .509 & .881 \\
\hline
\end{tabular}

In order to determine the significance of the studied relationships and the confidence intervals of the path coefficients, we used bootstrapping technique. The weighted coefficients indicate the relative strength of each exogenous construct. According to Chin (1998), relationships between constructs, with structural coefficients higher than 0.2 , are considered robust. From Table 5, we thus conclude that the original model does not present non-significant paths.

Table 5 Model's Path Coefficients

\begin{tabular}{llllll}
\hline \multirow{2}{*}{ Hypotheses } & $\begin{array}{l}\text { Original } \\
\text { Sample } \\
(\mathrm{O})\end{array}$ & $\begin{array}{l}\text { Sample } \\
\text { Mean } \\
(\mathrm{M})\end{array}$ & $\begin{array}{l}\text { Standard } \\
\text { Error } \\
(\text { STERR })\end{array}$ & $\begin{array}{l}\mathrm{T} \\
\text { Statistics } \\
(\mid \mathrm{O} / \text { STERR } \mid)\end{array}$ & $\begin{array}{l}\mathrm{p} \\
\text { values }\end{array}$ \\
\hline EO --> +REP & .488 & .523 & .194 & 2.509 & .012 \\
EO --> +ACEK & .587 & .626 & .114 & 5.154 & .000 \\
\hline
\end{tabular}

The significance of structural coefficients and the magnitude of the total effects enabled us to test the research hypotheses, having registered the following results:

H1. EO --> +REP - This hypothesis was supported;

H2. EO --> +ACEK - This hypothesis was supported;

Fig. 2 presents the final research structural model with the (direct) effects and explained variance of latent variables.

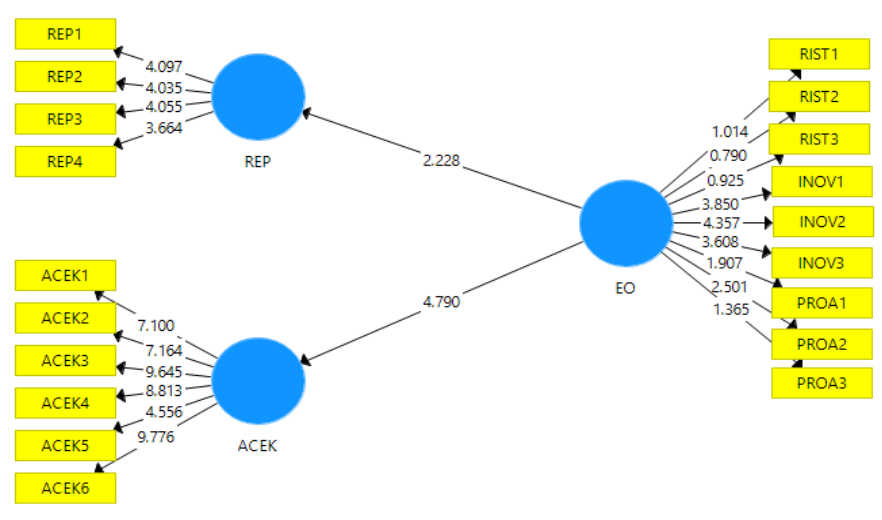

Fig. 2 Research structural model

\section{Discussion and conclusion}

The main purpose of this study is to analyse the influence of entrepreneurial orientation on reputational resources and knowledge exploitation. We conducted an empirical research based on a sample of 42 companies, which were applied a questionnaire in order to exploit data to test hypotheses, using proceedings and statistical techniques. It is important to note that companies evaluated entrepreneurial orientation and exploitation of knowledge relative to their major competitors in the export market(s), so the results should be interpreted based on these two aspects.

The Portuguese footwear industry faces considerable challenges, not only concerning the international markets crisis, but also regarding consumption patterns. The reduction of shoe design lifecycles has consequences on the offer. On one hand, the products have to be adapted to different segments specific needs and tastes (custom design, new models in small series, etc.), on the other hand, manufacture processes must be increasingly flexible, adopt just-in-time production, invest in the brand, qualified personnel, technology and innovation (APICCAPS, 2013).

This study demonstrated that the company's innovation and risk-taking have a positive and significant influence on knowledge exploitation. The analysed companies are able to exploit knowledge through informal knowledge gather, clear definition of tasks, analysis and discussion of market trends and new product development, among others. According to Guerreiro et al. (2016), entrepreneurial initiatives "depend on the knowledge produced".

Dynamic capabilities can take a variety of forms and be involved in different functions, but the most important common characteristics are that they are higher level capabilities which provide opportunities for knowledge gathering and sharing, constant updating the operational processes, interaction with the environment, and decision-making evaluations (EasterbySmith, Lyles and Peteraf, 2009). However, the existence of common features does not imply that any particular dynamic capability is exactly alike across firms, rather they could be developed from different starting points and take unique paths (Eisenhardt and Martin, 2000).

In fact, according to the industrial organization, a company should find a favourable position in its industry from which it can better defend against competitive forces, or to influence them in his favour through strategic actions such as raising barriers to entry, etc. (Porter, 1980). This perspective is consistent with Eisenhardt and Martin (2000) regarding the uniqueness of paths. The results of this study confirm that exploitation of knowledge enable firms to achieve superior long-term performance (Teece, 2007).

\subsection{Theoretical and practical implications}

It is known that strategy includes deliberate and emergent initiatives adopted by management, comprising resource and capabilities use to improve business performance (Nag, Hambrick and Chen, 2007). The findings are a contribution to clarify the influence of entrepreneurial orientation on the company's reputational resources. This study also enabled a thorough analysis of a highly important industry for national exports, such as footwear industry, allowing understanding that 
entrepreneurial orientation, as an industry strategic determinant, enhancing exploitation of knowledge.

Jansen et al. (2005) defend that companies need to develop organizational mechanisms to combine and apply newly acquired knowledge in order to deal and enhance each absorptive capacity dimension. In this study is notorious the importance of knowledge absorptive capacity to business performance. It is essential that business owners are able to interpret, integrate and apply external knowledge in order to systematically analyse change in the target market and to incorporate this knowledge in their processes to enhance performance.

In addition, the results provide guidance to business practitioners; because they indicate entrepreneurial orientation as a predictor for exploitation of knowledge. Companies are a bundle of resources and capabilities (Peteraf, 1993), it is essential to understand and identify which resources are relevant to gain competitive advantage and superior performance. In this study it is obvious the importance of entrepreneurial orientation to the firms' exploitation of knowledge. Business owners must be able to interpret, integrate and apply external knowledge in order to systematically analyse the changes that arise in their target mar$\operatorname{ket}(\mathrm{s})$ and to incorporate this knowledge into their processes, to identify the present and future needs and market trends, anticipate changes in demand and seek new business opportunities.

By building on the literature of entrepreneurial orientation, absorptive capacity and exploitation of knowledge, this study aims to support the strategic development of business management policies designed to increase firms' performance in foreign markets and add value to the current context of change.

\subsection{Research limitations}

The main limitation of this study is related to the sample size, since it was difficult to find companies with the willingness to collaborate in this type of research. The sample is non-probabilistic and convenience and cannot be used to infer to the general population. The study findings should therefore be analysed with caution.

The fact that the research does not consider the effect of control variables such as size, age, location and target market of the respondents can be seen as a limitation.

Finally, the fact that this study considered only exploitation of knowledge as an absorptive capacity can also be appointed as a limitation.

\subsection{Future lines of research}

In future work, we suggest that the model is used in a sample with a higher number of observations to confirm these results.

We further suggest pursuing with the investigation of strategic management in Portugal, focusing in other sectors of national economy, so that in the future one can make a comparison with similar studies, allowing realizing and finding new factors that enhance absorptive capacity.
Finally, the moderating effect of strategic variables (e.g. competitive advantage) in the relationship between entrepreneurial orientation and exploitation of knowledge should be studied.

\section{References}

Alvarez, S. A., Busenitz, L. W. (2001). The entrepreneurship of resource-based theory. Journal of Management. 27(6), pp. 755-775. https://doi.org/10.1177/014920630102700609

Ambrosini, V., Bowman, C. (2009). What are dynamic capabilities and are they a useful construct in strategic management? International Journal of Management Reviews. 11(1), pp. 29-49. https://doi.org/10.1111/j.1468-2370.2008.00251.x

Amit, R., Schoemaker, P. (1993). Strategic assets and organizational rent. Strategic Management Journal. 14(1), pp. 33-46.

APICCAPS (2013). Footure - Plano Estratégico - Cluster do Calçado. (Footure - Strategic Plan - Footwear Cluster.) APICCAPS: Associação Portuguesa dos Industriais de Calçado, Componentes, Artigos em Pele e seus Sucedâneos. (Portuguese Footwear, Components and Leather Goods Association (APICCAPS), Porto.) (in Portuguese)

Barreto, I. (2010). Dynamic Capabilities: A Review of Past Research and an Agenda for the Future. Journal of Management. 36(1), pp. 256-280. https://doi.org/10.1177/0149206309350776

Bowman, C., Ambrosini, V. (2003) How the Resource based and the Dynamic Capability Views of the Firm Inform Corporate level Strategy. British Journal of Management. 14(4), pp. 289-303.

https://doi.org/10.1111/j.1467-8551.2003.00380.x

Camisón, C., Forés, B. (2010). Knowledge absorptive capacity: New insights for its conceptualization and measurement. Journal of Business Research. 63(7), pp. 707-715. https://doi.org/10.1016/j.jbusres.2009.04.022

Carmines, E. G., Zeller, R. A. (1979). Reliability and Validity Assessment. Sage Publications, Newbury Park, CA.

Chin, W. W. (1998). The Partial Least Squares Approach to Structural Equation Modeling. Lawrence Erlbaum Associates, Publisher, Mahwah, New Jersey, London.

Chin, W. W. (2010). How to write up and report PLS analyses. In: Vinzi, V. E., Chin, W. W., Henseler, J., Wang, H. (eds.) Handbook of partial least squares: Concepts, methods and applications, (pp. 655-690.) SpringerVerlag, Berlin, Germany.

Chin, W. W., Newsted, P. R. (1999). Structural Equation Modeling Analysis with Small Samples Using Partial Least Squares. In: Hoyle, R. (ed.) Statistical Strategies for Small Sample Research. (pp. 307-341), Sage Publications, Thousand Oaks, CA.

Cohen, W. M., Levinthal, D. A. (1990) Absorptive Capacity: A New Perspective on Learning and Innovation. Administrative Science Quarterly. 35(1), pp. 128-152. https://doi.org/10.2307/2393553

Covin, J., Miles, M. (1999) Corporate entrepreneurship and the pursuit of competitive advantage. Entrepreneurship: Theory and Practice. 23(3), pp. 47-63.

Covin, J., Miller, D. (2014). International Entrepreneurial Orientation: Conceptual Considerations, Research Themes, Measurement Issues, and Future Research Directions. Entrepreneurship Theory and Practice. 38(1), pp. 11-44. https://doi.org/10.1111/etap.12027

Covin, J., Slevin, D. (1989). Strategic management of small firms in hostile and benign environments. Strategic Management Journal. 10(1), pp. 75-87. https://doi.org/10.1002/smj.4250100107

Covin, J., Slevin, D. (1991). A conceptual model of entrepreneurship as firm behavior. Entrepreneurship: Theory and Practice. 16(1), pp.7-25.

Davis, J. L., Bell, R. G., Payne, G. T., Kreiser, P. M. (2010) Entrepreneurial Orientation and Firm Performance: The Moderating Role of Managerial Power. American Journal of Business. 25(2), pp. 41-54. https://doi.org/10.1108/19355181201000009 
DeVellis, R. F. (2012). Scale Development - Theory and Applications. 3rd ed. SAGE Publications, Inc., Chapel Hill (USA).

Easterby-Smith, M., Lyles, M. A., Peteraf, M. A (2009). Dynamic Capabilities: Current Debates and Future Directions. British Journal of Management. 20(1), pp. S1-S8. https://doi.org/10.1111/j.1467-8551.2008.00609.x

Eisenhardt, K. M., Martin, J. A. (2000). Dynamic capabilities: what are they? Strategic Management Journal. 21(10-11), pp. 1105-1121. https:// doi.org/10.1002/1097-0266(200010/11)21:10/11<1105::AID-SM$\mathrm{J} 133>3.0 . \mathrm{CO} ; 2-\mathrm{E}$

Frank, H., Kessler, A., Fink, M. (2010). Entrepreneurial orientation and business performance-a replication study. Schmalenbach Business Review. 62, pp. $175-198$.

Fornell, C., Larcker, D. F. (1981). Evaluating structural equation models with unobservable variables and measurement error. Journal of Marketing Research. 18(1), pp. 39-50. https://doi.org/10.2307/3151312

Gefen, D., Straub, D. (2005). A Practical Guide To Factorial Validity Using PLS-Graph: Tutorial And Annotated Example. Communications of the Association for Information Systems. 16, pp. 91-109.

Guerreiro, M. D., Caetano, A., Eduardo Rodrigues, E., Barroso, M., Couto, A. I. (2016). Becoming an Entrepreneur: a Diversity of Factors, Types and Pathways. Periodica Polytechnica Social and Management Sciences. 24(2), pp. 74-82. https://doi.org/10.3311/PPso.8688

Henseler, J., Ringle, C. M., Sinkovics, R. R. (2009). The use of Partial Lesat Squares Path Modeling in international marketing. In: Sinkovics, R. R., Ghauri, P. N. (eds.) New Challenges to International Marketing (Advances in International Marketing), 20. (pp. 277-319.). Emerald Group Publishing Limited.

Jansen, J. J. P., Van Den Bosch, F. A. J., Volberda, H. W. (2005). Managing Potential and Realized Absorptive Capacity: How Do Organizational Antecedents Matter? Academy of Management Journal. 48(6), pp. 999-1015. https://doi.org/10.5465/AMJ.2005.19573106

Khandwalla, P. N. (1977). Some top management styles, their context and performance. Organization and Administrative Sciences. 7(4), pp. 21-51.

Kreiser, P., Marino, L., Weaver, K. (2002). Assessing the psychometric properties of the entrepreneurial orientation scale: A multi-country analysis. Entrepreneurship Theory and Practice. 26(4), pp. 71-94.

Lisboa, A., Skarmeas, D., Lages, C. (2011). Entrepreneurial orientation, exploitative and explorative capabilities, and performance outcomes in export markets: A resource-based approach. Industrial Marketing Management. 40(8), pp. 1274-1284. https://doi.org/10.1016/j.indmarman.2011.10.013

Lumpkin, G., Dess, G. (1996). Clarifying the entrepreneurial orientation construct and linking it to performance. Academy of management Review. 21(1), pp. 135-172.

Marôco, J. (2011). Análise estatística com o SPSS Statistics. (Statistical analysis with SPSS Statistics.), $5^{\text {th }}$ ed., ReportNumber, Lda, Pêro Pinheiro. (in Portuguese)

Menon, A., Bharadwaj, S. G., Adidam, P. T., Edison, S. W. (1999). Antecedents and consequences of marketing strategy making: a model and a test. Journal of Marketing. 63(2), pp. 18-40. https://doi.org/10.2307/1251943

Miller, D. (1983). The correlates of entrepreneurship in three types of firms. Management Science. 29(7), pp. 770-791.

Mintzberg, H. (1973). Strategy-making in three modes. California Management Review. 16(2), pp. 44-53. https://doi.org/10.2307/41164491

Monteiro, A., Soares, A. M., Rua, O. L. (2017). Entrepreneurial orientation and export performance: the mediating effect of organisational resources and dynamic capabilities. Journal of International Business and Entrepreneurship Development. 10(1), pp. 3-20. https://doi.org/10.1504/JIBED.2017.082749
Nag, R., Hambrick, D., Chen, M. (2007). What is strategic management, really? Inductive derivation of a consensus definition of the field. Strategic Management Journal. 28(9), pp. 935-955.

https://doi.org/10.1002/smj.615

Nunnally, J. C. (1978). Psychometric theory. McGraw-Hill, New York.

Okpara, J. (2009). Entrepreneurial orientation and export performance: evidence from an emerging economy. International Review of Business Research Papers. 5(6), pp. 195-211.

Pestana, M. H., Gageiro, J. N. (2008) Análise de Dados para Ciências Sociais - A complementaridade do SPSS. (Analysis of data for social sciences - The complementarity of SPSS.), $5^{\text {th }}$ ed., Edições Silabo, Lisboa. (in Portuguese)

Peteraf, M. (1993). The cornerstones of competitive advantage: A resource-based view. Strategic Management Journal. 14(3), pp. 179-191. https://doi.org/10.1002/smj.4250140303

Porter, M. (1980). Competitive Strategy. Free Press, New York.

Roldán, J. L., Cepeda, G. (2014). Partial Least Squares (PLS) para investigadores en ciências sociales. (Partial least squares (PLS) for researchers in social sciences.) Departamento de Administración de Empresas y Marketing, Universidad de Sevilla. (in Spanish)

Reinartz, W., Haenlein, M., Henseler, J. (2009). An empirical comparison of the efficacy of covariance-based and variance-based SEM. International Journal of Research in Marketing. 26(4), pp. 332-344. https://doi.org/10.1016/j.ijresmar.2009.08.001

Teece, D. J. (2007). Explicating dynamic capabilities : the nature and microfoundations of (sustainable) enterprise performance. Strategic Management Journal. 28(13), pp. 1319-1350. https://doi.org/10.1002/smj.640

Teece, D. J., Pisano, G., Shuen, A. (1997). Dynamic capabilities and strategic management. Strategic Management Journal. 18(7), pp. 509-533. https://doi.org/10.1002/(SICI)1097-0266(199708)18:7<509::AIDSMJ882>3.0.CO;2-Z

Tzokas, N., Kim, Y. A., Akbar, H., Al-Dajani, H. (2015). Absorptive capacity and performance: The role of customer relationship and technological capabilities in high-tech SMEs. Industrial Marketing Management. 47, pp. 134-142. https://doi.org/10.1016/j.indmarman.2015.02.033

Wang, C., Ahmed, P. K. (2007). Dynamic capabilities: A review and research agenda. International Journal of Management Reviews. 9(1), pp. 31-51.

Wiklund, J. (2006). The sustainability of the entrepreneurial orientation-performance relationship. In: Davidsson, P., Delmar, F., Wiklund, J. (eds.) Entrepreneurship and the Growth of Firms. (pp. 141-155.) Edward Elgar, Northampton, MA.

Wiklund, J., Shepherd, D. (2005). Entrepreneurial orientation and small business performance: a configurational approach. Journal of Business Venturing. 20(1), pp. 71-91. https://doi.org/10.1016/j.jbusvent.2004.01.001

Zahra, S., Covin, J. G. (1995). Contextual influences on the corporate entrepreneurship-performance relationship: A longitudinal analysis. Journal of Business Venturing. 10(1), pp. 43-58. https://doi.org/10.1016/0883-9026(94)00004-E

Zahra, S., Garvis, D. (2000). International corporate entrepreneurship and firm performance: The moderating effect of international environmental hostility. Journal of Business Venturing. 15(5-6), pp. 469-492. https://doi.org/10.1016/S0883-9026(99)00036-1

Zahra, S., George, G. (2002). Absorptive capacity: A review, reconceptualization, and extension. Academy of Management Review. 27(2), pp. 185-203. 